Saudi Journal of Business and Management Studies Abbreviated Key Title: Saudi J Bus Manag Stud ISSN 2415-6663 (Print) |ISSN 2415-6671 (Online) Scholars Middle East Publishers, Dubai, United Arab Emirates Journal homepage: https://saudijournals.com/sjbms

Original Research Article

\title{
Effect of Company Size, Audit Profitability, Leverage, and Audit Opinion on Audir Delay with Audit Quality as Moderators (Empirical Study of Listed Mining Companies on the Indonesia Stock Exchange for the 2014-2018 Period)
}

Rindi Yuyanti" , Hadri Mulya

Department of Accounting Universitas Mercu Buana, Indonesia

DOI: $10.36348 /$ sjbms.2020.v05i06.007 $\quad$ | Received: 04.06.2020 | Accepted: 22.06 .2020 | Published: 28.06 .2020

*Corresponding author: Rindi Yuyanti

\section{Abstract}

The purpose of this research is to analyze the influence of company size, profitability, Leverage, and opinion Audit on the Audit Delay on mining Listed on the Indonesia Stock Exchange period 2014 - 2018. And to analyze whether Audit quality can moderate company size, profitability, Leverage, and opinion Audit on the Audit Delay on the mining listed on the Indonesia Stock Exchange period 2014 - 2018. The method used is a quantitative method. The population in this study is all companies included in the mining sector listed on the Indonesia Stock exchange for five years, $2014-2018$. Determination of the number of samples carried out using purposive sampling technique with non probability sampling technique so that the samples used in this study as much as 91 companies. The data collection techniques in this research are done in several ways, namely with documentation and library studies. The Data obtained was subsequently analyzed with a double linear regression analysis model using SPSS program support version 20.00. However, before the multiple regression analyses were first carried out analysis of the descriptive statistical regression and test of classical assumptions. The results showed that profitability, Leverage and Audit opinions have significant effect on Audit Delay. Meanwhile, company size has no effect on Audit Delay. Also for quality auditing is able to moderate company size, profitability, and Leverage on Audit Delay. Audit quality does not moderate the influence of Audit opinions on Audit Delay.

Keywords: Company size, profitability, Leverage, opinion Audit, quality audit, and Audit Delay.

Copyright @ 2020: This is an open-access article distributed under the terms of the Creative Commons Attribution license which permits unrestricted use, distribution, and reproduction in any medium for non-commercial use (NonCommercial, or CC-BY-NC) provided the original author and source are credited.

\section{INTRODUCTION}

The Audit of financial statements aims to provide an opinion on the fairness and suitability of the financial statements with the applicable principles. Audited financial statements are conducted to provide assurance for the reliability of financial statements. PSAK No. 1 year 2018 also mentions that financial statements should have qualitative characteristics of useful financial information. In order for the information to be useful, the information must be relevant and represent precisely what will be presented. The use of financial information can be improved if the information is comparable, verified (verifiable), timely (timely), and understandable (understandable). Audit delay is the length of day that auditors need to complete their audit work, which is measured from the closing date of the book year until the date of publication of the audit result report.

Indonesia Stock Exchange (IDX) recorded that there were 63 registered companies or issuers have not delivered an annual report of 2015 in a timely manner until 2 May 2016. In 2016 the Indonesian Stock Exchange (IDX) sentenced the stock trading suspension penalty to the issuer that has not delivered the audited financial statement as of December 31, 2016. At least 17 issuers are subject to the sanction. In 2017 the Indonesian Stock Exchange (IDX) found 10 listed companies that have not yet delivered the audited 
financial statements as of December 31, 2017 and or have not made a penalty payment for the late submission of financial statements. And in 2018 Indonesia Stock Exchange (IDX) recorded until Tuesday yesterday (9/4) new 626 registered company (issuer) both shares and bonds that released financial report (LAPKEU) book year 2018 from a total of 690 companies that have a delivery obligation.

Based on the data above, many factors can extend the audit delay such as internal factors of the company and external factors that become a barrier in the auditing process. Some companies are late delivering financial statements from the year 20152018. There are several factors affecting the Audit delay, including profitability, solvency, and activity. Research by Pourali, et al. [1], stated that large enterprise management has the urge to reduce the audit delay and delay the submission of financial statements, which are caused because these companies are closely monitored by investors, capital supervisors and governments. According to research Ashton, et al. [2] and Khalatbari, et al. [3] and Purnamasari [4], large companies reported faster than small companies. Thus it can be said the size of the company is a factor that affects audit delay. Companies with higher profitability rates are suspected that the audit delay will be shorter than the company with a lower profitability level. Lianto and Kusuma [5] and Purnamasari [4] showing the results of research on profitability affect the audit delay. Solvency demonstrates the company's ability to meet all of its financial obligations when the company is liquidated. Lianto and Kusuma [5] revealed that the relative proportion of debts to total assets indicates the financial condition of the company. Wirakusuma [6] found the influence of solvency on the audit delay. The greater the ratio of debt to total assets will be the longer the range of audit delay. Hossain Research [7] and Taylor showing the quality of auditors negatively affect delay audits. The results of this study were inconsistent with the research of Carslaw and Kaplan [8] who found the quality of Auditors had no effect on the audit delay.

Based on the background above, the authors want to take the research discussion under the title "Influence of company size, profitability, Leverage, and Audit opinion on Audit Delay with quality Audit as a moderate" in the mining company sector company Listed on the Indonesia Stock Exchange period 20142018.

\section{LITERATURE REVIEW}

Audit delay is the completion time range of the annual financial report audit, based on the length of day required to obtain the independent auditor's report on the company's annual financial report audit, as from the closing date of the company's book year, as per 31 December until the date on the independent auditor's report Wulandari and Utama [9]. The audit delay is the length or time span of the audit which is measured from the closing date of the book year to the date of the publication of Purnamasari Audit report [4]. Puspitasari and Sari [10] Audit delay is the time span of the completion of the annual financial report audit measured by the length of day required to obtain the independent auditor's report on the company's annual financial report audit, as from the closing date of the company book.

According to Nirmalasari [11], the size of the company is a value that shows the big little Company. Meanwhile, according to Nirmalasari [11] defines the size of the company as a large small company that is measured by using the total assets owned by the company or total assets of the client company listed in the company's financial statements of the end of the audited period using the log size. The size of the company is a large small company measured by the amount of total assets or wealth owned by a company [6]. Hersugondo \& Kartika [12] stated that large corporations were more consistent in time than small companies in informing their financial reports.

Profitability is one of the measurements for the performance of a company, the profitability of a company showing the ability of a company to generate profit during a certain period at the level of sales, assets and capital of the particular stock [9]. Profitability is a measure of the company's ability to generate profits over a certain period. Meanwhile, according to Riyanto [13] According to Riyanto [14] Profitability is the ability of a company to generate profits over a certain period. And according to Fahmi [15] profitability is the ratio that measures the effectiveness of overall management directed by the large level of profit gained in relation to sales and investment.

Sunaningsih [16], stating the ratio of leverage is the ratio used to measure the company's ability to pay for both short-term and long-term obligations when the company is liquidated. The solvency ratio is the ratio used to measure the extent to which the company's assets are financed by debt $[17,18]$. That is, how much debt is borne by the company compared with its assets $[10,18]$. The Weston \& Copeland [6] states the higher the leverage level the company reflects the increasingly high risk of the company. The company's high risk indicates that the company is experiencing financial difficulties. Financial difficulties are bad news that will affect the company's condition in the eyes of the community. Management tends to delay the delivery of bad news from the company to investors and other parties.

Audit is the activity of collecting and evaluating evidence of information on predefined criteria in order to determine and report the degree of conformity [10]. Auditing is a systematic and objective process of collecting and evaluating evidence of management statements relating to economic events to 
ensure the conformity of comparisons between existing statements and certain criteria and conveying the results to shareholder [13]. According to Arens et al. [4] The audit opinion is a standard statement of the auditor's conclusion obtained from the audit process based on the evidence and findings evaluated during carrying out its duties. Audit standards are mandatory guidelines for auditors in the implementation of auditing measures. According to Jusup [10] "Audit standards are a common form to assist auditors in fulfilling their professional responsibilities in auditing the historical financial statements"

According to the research of Khalatbari, et al. [3] and Purnamasari [4], large companies reported faster than small companies. Thus it can be said the size of the company is a factor that affects the audit delay, Mafizatun Nurhayati [19]. The size of the company is negatively influential but significant to the dividend policy. The company's profitability has a positive and significant effect on dividend policy.

The company's liquidity (Current ratio) has a negative coefficient. The company's profitability relates positively and significantly to the company's value. The company's size positively and significantly affects the value of the company. The findings of this research show that investors consider the company's liquidity (Current ratio) not to have a significant influence on the value of the company. The dividend policy does not affect the value of the company. Companies with higher profitability rates are suspected that the audit delay will be shorter than the company with a lower profitability level. Lianto and Kusuma [5] and Purnamasari [4]. Waluyo [20] that tax efficiency, profitability and asset growth (with a significance rate of 5\%) Impact the leverage. This suggests that companies are more likely to use taxes efficiently by maximizing costs, which can be mitigated by debt use. The high proportion of the debt to the total asset, will affect the liquidity associated with the company's survival problems (going concern), which ultimately requires deeper auditing. Wirakusuma [21] found the influence of positive leverage on the audit delay. The greater the ratio of debt to total assets will be the longer the range of audit delay. Auditors will provide unreasonable opinions if the client's financial statements are not drafted based on the general accounting principles in Indonesia so as not to present a reasonable financial position, business results, changes in equity and cash flow of the client company. In addition, the auditor gives unnatural opinion that it is not limited to the scope of the audit, so that the auditor can collect enough competent evidence to support his opinion [22]. Haryani [16] declares the quality of audits as all possible where an auditor at the time of auditing the client's financial statements can find violations that occur in the client's accounting system and report them in the audited financial statements. The audit quality strengthened the company's size against the audit delay. Oktorina and Suharli [23] stated that the big HOOD has better audit quality. Companies that use KAP services such as The Big Four tend to be preferred by investors because investors consider companies with large KAP will be able to produce good quality audits rather than small KAP. Because of the many investors who choose a company with a big HOOD, then the profitability of the company will certainly increase. A company with a high financial leverage means having a high financial risk due to financial difficulties. Thus, the auditor will take longer time to perform the audit completion, because more proof to convince the truth of the debt level, so that there is no time in the publication of financial statements [8]. Haryani [16] declares the quality of audits as all possible where an auditor at the time of auditing the client's financial statements can find violations that occur in the client's accounting system and report them in the audited financial statements. The quality of audit is strengthened by audit delay. Based on the above, hypotheses are taken as follows:

H1: Company size affects audit delay

$\mathrm{H} 2$ : Profitability affects the audit delay

H3: Leverage affects audit delay

H4: Audit opinion affects audit delay

H5: Audit quality moderate size of company affect audit delay

H6: Audit quality moderate profitability affects the audit delay

H7: Audit Quality moderate Leverage impact on audit delay

H8: Audit Quality moderate audit opinions effect on audit delay 


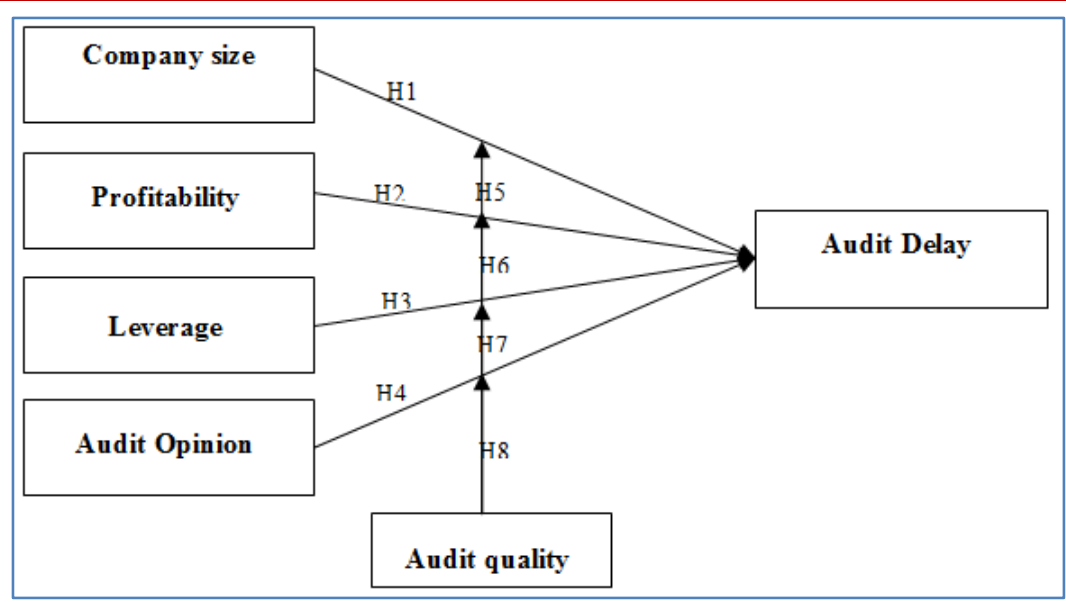

Fig-1: The research model

\section{METHODOLOGY}

This research is a type of quantitative research, reviewed from the level of explanation of this research is an associative research with the form of causal relationships. According to Sugiyono [16] A causal relationship is a cause of consequence.

This research uses secondary data which is data which is the annual document/financial report of the mining company registered in IDX period 20142018 which is the written data relating to the research object published by the company and IDX.

Sampling is done using purposive sampling method with non probability sampling technique, i.e. sampling technique based on certain criteria. The criteria used to determine the samples in this study were:

A. The mining company listed on the Indonesia Stock exchange for five years is $2014-2018$.

B. The mining company contains and publishes financial statements that expire on 31 December period 2014-2018.

C. Mining companies that have not delisting during the observation period.

\section{RESEARCH METHODS}

The size of the company has no effect on audit delay because the larger a company, the management will be more concentrated on the accuracy of the results of financial statements and how well the numbers in the financial statements affect investors' perceptions of company performance. Thus, company management is not too focused on the aspects of the speed or duration of the audit process, but rather on the achievement of company performance results. States that Profitability has a significant effect on Audit Delay indicating that the greater the company's ability to generate profits, the faster the audit process occurs to shorten the audit delay range. Conversely, the smaller the company's ability to generate profits, the longer the audit process that occurs to extend the audit delay range. The influence of leverage on audit delay shows that a high proportion of debt to total assets will affect liquidity associated with the company's survival problems, which ultimately requires more careful auditing. And the greater the risk of debt to total assets, the lower the audit delay. The greater the debt owned by the company, the longer the audit process that occurs to extend the audit delay range. Audit opinion is a factor that influences audit delay

It can be said that companies that accept or have qualified opinion opinions will experience increasingly longer audit delays caused by auditing processes that involve negotiation with clients as well as consultation with higher or more senior audit partners. Compared to companies that receive or receive an unqualified opinion, the audit delay is shorter or does not take a long time because the company will not delay the publication of financial statements in accordance with the provisions of the FSA 4 months from closing the book. Audit quality plays a role in supporting large companies in the timeliness of financial reporting, where large companies tend to have a good image in the public eye. The size of the company is increasingly large, causing more and more attention from both investors and the government, this also makes companies very selective in choosing audit quality services, and large companies have enormous demands to accelerate the reporting of financial statements.

Audit quality moderating the effect of profitability on audit delay can be proven by companies that use KAP services such as The Big Four (Pwc, Deloitte, EY and KPMG) tend to be preferred by investors than companies that do not use the services of Big Four KAP, because investors assume that companies with large KAP will be able to produce better audit quality than small KAP. Therefore, many investors choose companies with large KAP, so the profitability of the company will certainly increase. The selection of KAP in partnership with The Big Four is carried out in order to audit more efficiently and effectively, and have greater flexibility in order to reduce inaccuracies in the publication of financial 
statements. Being audit quality factor moderates leverage against audit delay.

After analyzing, it shows that the company audited by the Big Four KAP will issue the right opinion without any errors in expressing opinions or can be said to minimize errors in expressing opinions. In contrast to companies audited by Non Big Four there is a possibility of error in expressing their opinion which makes audit quality not moderate the effect of audit opinion on audit delay.

\section{DATA ANALYSIS}

Table-1: Descriptive Statistical Analysis Results

\begin{tabular}{|l|l|l|l|l|l|}
\hline & N & Minimum & Maximum & Mean & Std. Deviation \\
\hline SIZE (in billion Rp) & 190 & 128,00 & 100591,00 & 11811,4579 & 1816,80373 \\
\hline ROA (rasio) & 190 & $-6,44$ & 11,12 &, 2974 & 1,34186 \\
\hline DER (rasio) & 190 & $-15,82$ & 34,06 & 1,3173 & 3,47929 \\
\hline OPINI (dummy) & 190 &, 00 & 1,00 &, 9737 &, 16050 \\
\hline KAP (dummy) & 190 &, 00 & 1,00 &, 4368 &, 49731 \\
\hline AUDIT (hari) & 190 & 8,00 & 274,00 & 81,5947 & 31,20336 \\
\hline Valid N (listwise) & 190 & & & & \\
\hline
\end{tabular}

Source: Results of data processing with SPSS (2014)

Based on the table 4.1 above, it can be explained that the company size (total assets) obtained a minimum value of Rp. 128 billion and a maximum of Rp. 100.591 billion with a mean of Rp. 11.811 billion resulted in a standard deviation of 1,816. For the profitability variable (ROA) it generates a minimum value of-6.44 and a maximum value of 11.12 with a mean of 0.2974 generates a standard deviation of 1.34186. For Leverage variable (DER) it generates a minimum value of-15.82 and a maximum value of 34.06 with a mean of 1.3173 generates a standard deviation of 3.47929. Further, the results of the descriptive statistical test for the Audit opinion variable (OPINI) obtained a minimum value of 0.00 and a minimum of 1.00 with a mean of 0.9737 and a standard deviation of 0.16050 . For the audit quality (KAP) has a minimum value of 0.00 and a maximum of 1.00 with a mean of 0.4368 and a standard deviation of 0.49731 . The results of the descriptive statistical test showed that the audit delay obtained a minimum value of 8.00 and a maximum of 274.00 with a mean of 81.5947 and a standard deviation of 31.20336. Classical Assumptions

Table-2: Test results for normality with Kolmogrov-Smirnov

\begin{tabular}{|l|l|l|}
\hline \multicolumn{2}{|c|}{ One-Sample Kolmogorov-Smirnov Test } \\
\hline N & $\begin{array}{l}\text { Unstandardize } \\
\text { d Residual }\end{array}$ \\
\hline \multirow{2}{*}{ Normal Parameters ${ }^{\text {a,b }}$} & 190 \\
\cline { 2 - 3 } & Mean &, 0000000 \\
\hline \multirow{2}{*}{ Most Extreme Differences } & Std. Deviation & 22,29404399 \\
\cline { 2 - 3 } & Absolute &, 134 \\
\cline { 2 - 3 } & Positive &, 134 \\
\cline { 2 - 3 } & Negative &,- 071 \\
\hline Kolmogorov-Smirnov Z & 1,849 \\
\hline Asymp. Sig. (2-tailed) &, 502 \\
\hline a. Test distribution is Normal. \\
\hline b. Calculated from data. \\
\hline
\end{tabular}

Source: Results of data processing with SPSS (2014)

The table 4.2 above shows that the value is significant for the unstandardized residual of 0.502 . This value is not significant for the unstandardized residual variable is greater than 0.05 , it can be concluded that the data on the variable is normal distribution. The above result indicates that the data is distributed normally.

Tabel-3: Multicollinearity Testing Results

\begin{tabular}{|l|l|l|l|}
\hline Independent Variable & TOL & VIF & Conclusion \\
\hline SIZE & 0,781 & 1,280 & There is no multicollinearity \\
\hline ROA & 0,861 & 1,162 & There is no multicollinearity \\
\hline DER & 0,985 & 1,015 & There is no multicollinearity \\
\hline OPINI & 0,896 & 1,116 & There is no multicollinearity \\
KAP & 0,721 & 1,387 & There is no multicollinearity \\
\hline
\end{tabular}

Source: Results of data processing with SPSS (2014) 
According to the 4.3 table, it is known that each variable has a VIF value of $<10$ and Tolerance $>$ 0.10 . These results indicate that the company size, profitability, Leverage, Audit opinions and Audit quality are not correlated. With Demikain regression model is spared from the problem of multicolinearity.

Tabel-4: Heteroskedasititas test Results

\begin{tabular}{|l|l|l|}
\hline Independent Variable & sig & Conclusion \\
\hline SIZE & 0,090 & There is no multicollinearity \\
\hline ROA & 0,215 & There is no multicollinearity \\
\hline DER & 0,090 & There is no multicollinearity \\
\hline OPINI & 0,562 & There is no multicollinearity \\
KAP & 0,486 & There is no multicollinearity \\
\hline
\end{tabular}

Source: Results of data processing with SPSS (2014)

The results of heteroskedasitity test in the table above, indicating that the significant value in the variable enterprise size, profitability, Leverage, opinion Audit and Audit quality have a significant value greater than 0.05. So it can be said that the independent variables are free from the problem of Heteroskedasititas. Autocorrelation

Tabel-5: Autocorrelation Testing Results

\begin{tabular}{|l|l|l|l|l|l|}
\hline $\begin{array}{l}\mathbf{N} \\
\text { K= 4 }\end{array}$ & DW hitung & 4-dU & 4-dL & Tabel Dw Batas Bawah (dl) & Tabel DW Batas Atas (du) \\
\hline 190 & 1,908 & 2,190 & 2,272 & 1,728 & 1,810 \\
\hline
\end{tabular}

Source: Results of data processing with SPSS (2014)

The test results on the entire data in this study showed that no autocorrelation occurred. It is shown from the value $\mathrm{dU}(1.810)<\mathrm{dW}(1.908)<(4-\mathrm{dU})$ (2.190), then no autocorrelation occurs.

Tabel-6: Regression Testing Results

\begin{tabular}{|c|c|c|c|c|c|c|}
\hline \multicolumn{2}{|c|}{ Model } & \multicolumn{2}{|c|}{ Unstandardized Coefficients } & $\begin{array}{l}\text { Standardized Coefficients } \\
\text { Beta }\end{array}$ & $\mathbf{t}$ & Sig. \\
\hline \multirow[t]{9}{*}{1} & (Constant) & 122,485 & 24,491 & & 5,001 & 000 \\
\hline & SIZE & 2,581 & 1,357 & ,124 & 1,901 &, 059 \\
\hline & ROA & $-16,853$ & 1,856 &,- 725 & $-9,080$ &, 000 \\
\hline & DER & $-1,490$ & 402 &,- 166 & $-3,710$ & ,000 \\
\hline & OPINI & $-70,750$ & 9,463 &,- 364 & $-7,476$ & ,000 \\
\hline & SIZE_KAP & $-4,994$ & 2,112 & $-1,280$ & $-2,365$ &, 019 \\
\hline & ROA_KAP & 18,807 & 2,323 & 653 & 8,096 &, 000 \\
\hline & DER_KAP & 12,216 & 2,514 & 294 & 4,860 &, 000 \\
\hline & OPINI_KAP & 43,344 & 32,672 & 691 & 1,327 &, 186 \\
\hline
\end{tabular}

Source: Results of data processing with SPSS (2014)

From the regression test results above, the regression equation is obtained as follows:

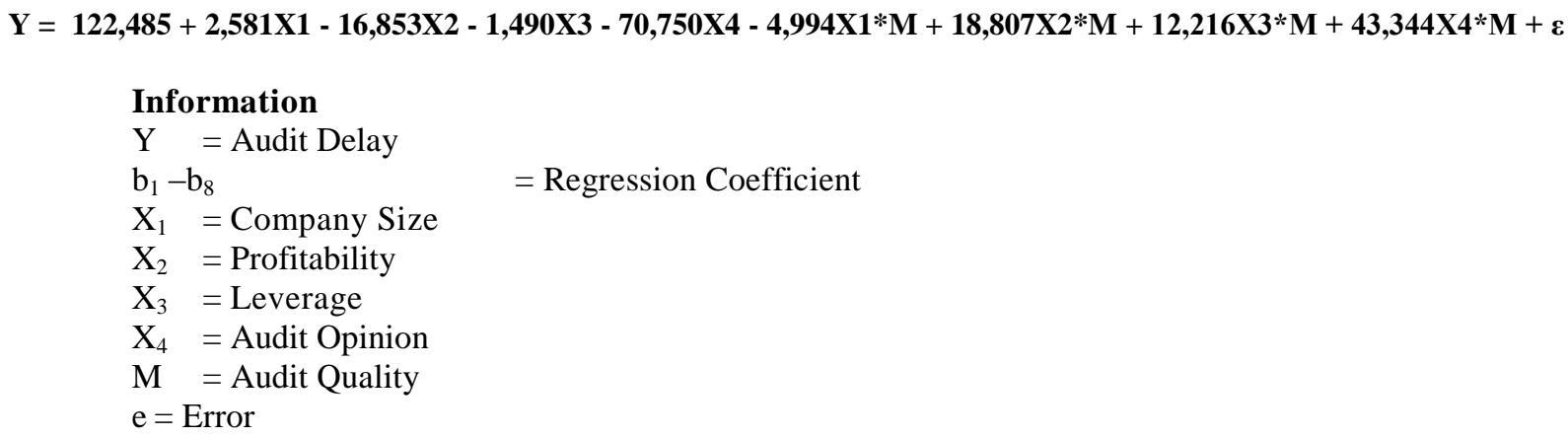


Tabel-7: Determination Coefficient Test Results

\begin{tabular}{|c|c|c|c|c|c|}
\hline \multicolumn{6}{|c|}{ Model Summary } \\
\hline Model & & $\mathrm{R}$ & R Square & Adjusted R Square & Std. Error of the Estimate \\
\hline dimension & 1 &, $811^{\mathrm{a}}$ &, 657 & ,642 & 18,67157 \\
\hline
\end{tabular}

According to table 4.7 It is known that RSquare Adjused value amounted to 0.642. From the results of the calculations obtained the result of the effect of independent variables on the dependent variables that can be explained by this equation model is $64.20 \%$. This suggests that large variable influences of SIZE, ROA, DER, OPINION, SIZE KAP, ROA_KAP, DER_KAP and OPINI_KAP against Audit Delay can be explained by the model of the equation is $64.20 \%$ and the remaining $35.80 \%$ is influenced by other factors that are not included in the regression model.

Tabel-8: Test Results F (Simultaneous Hypothesis)

\begin{tabular}{|l|l|l|l|l|l|l|}
\hline \multicolumn{7}{|c|}{ ANOVA $^{\mathbf{b}}$} \\
\hline Model & Sum of Squares & df & Mean Square & F & Sig. \\
\hline \multirow{2}{*}{1} & Regression & 120918,221 & 8 & 15114,778 & 43,355 &, $000^{\mathbf{a}}$ \\
\cline { 2 - 7 } & Residual & 63101,573 & 181 & 348,627 & & \\
\cline { 2 - 3 } & Total & 184019,795 & 189 & & & \\
\hline
\end{tabular}

According to table 4.6 obtained a significant value of 0.000 . The significant value obtained is smaller than $0.05(0.000<0.05)$ meaning Ho9 is rejected and $\mathrm{Ha} 9$ is accepted. Thus, the results showed that SIZE,
ROA, DER, OPINI, SIZE_KAP, ROA_KAP, DER_KAP and OPINI_KAP had an effect on the Audit Delay on the IDX-listed mining company 2014-2018.

Tabel-9: T Test Results (Partial Hypothesis)

\begin{tabular}{|c|c|c|c|c|c|c|}
\hline \multicolumn{2}{|c|}{ Model } & \multicolumn{2}{|c|}{ Unstandardized Coefficients } & $\begin{array}{l}\text { Standardized } \\
\text { Coefficients } \\
\text { Beta } \\
\end{array}$ & $\mathbf{t}$ & Sig. \\
\hline \multirow[t]{9}{*}{1} & (Constant) & 122,485 & 24,491 & & 5,001 & 000 \\
\hline & SIZE & 2,581 & 1,357 &, 124 & 1,901 &, 059 \\
\hline & ROA & $-16,853$ & 1,856 &,- 725 & $-9,080$ &, 000 \\
\hline & DER & $-1,490$ &, 402 &,- 166 & $-3,710$ &, 000 \\
\hline & OPINI & $-70,750$ & 9,463 &,- 364 & $-7,476$ &, 000 \\
\hline & SIZE_KAP & $-4,994$ & 2,112 & $-1,280$ & $-2,365$ & ,019 \\
\hline & ROA_KAP & 18,807 & 2,323 & ,653 & 8,096 &, 000 \\
\hline & DER_KAP & 12,216 & 2,514 & 294 & 4,860 &, 000 \\
\hline & $\begin{array}{l}\text { OPINI_KA } \\
\mathrm{P}\end{array}$ & 43,344 & 32,672 & ,691 & 1,327 & 186 \\
\hline
\end{tabular}


Based on the results of the $\mathrm{T}$ test in table 4.9 above, it can be created the following hypothesis testing. That the company size variable gained a significant value of 0.059 . The significant value is greater than $0.05(0.059>0.05)$, and a coefficient value of 2.581 indicates Ho1 is received and HA1 is rejected. These results indicate that company size has no effect on Audit Delay. It can be explained that the profitability variable obtains a significant value of 0.000 . The significant value is smaller than $0.05(0.000<0.05)$, and a coefficient value of-16.853 indicates Ho1 rejected and HA1 is received. The results showed that a significant negative profitability impact on the Audit Delay variable Leverage gained a significant value of 0.000 . A significant value smaller than $0.05(0.000>$ 0.05 ), and a coefficient value of-1.490. However, due to the negative value of the beta $\mathrm{Ho} 3$ accepted and Ha3 rejected. The results showed that Leverage is significant but negative against Audit Delay can be explained that the Audit opinion variables have a significant value of 0.000 . The significant value is smaller than $0.05(0.000$ $<0.05)$, and a coefficient value of-70.750 indicates Ho4 rejected and HA4 received. The results showed that the Audit opinion has a significant negative effect on the Audit Delay variable SIZE_KAP obtained a significant value of 0.019 . A significant value smaller than 0.05 $(0.019<0.05)$, and a coefficient value of -4.994 shows Ho5 rejected and Ha5 accepted. The results showed that Audit quality is moderate influence of corporate size the Audit Delay that the ROA_KAP variable obtained a significant value of 0.000 . A significant value smaller than $0.05(0.000<0.05)$, and a coefficient value of 18.807 showed Ho6 rejected and Ha6 received. The results showed that the Audit quality moderate the impact of profitability on the Audit Delay. The DER_KAP variable obtained a significant value of 0.000 . A significant value that is smaller than 0.05 $(0.000<0.05)$, and a coefficient value of 12.216 shows $\mathrm{Ho} 7$ rejected and $\mathrm{Ha} 7$ received. The results indicated that the Audit quality moderate influence Leverage is an Audit Delay. That the OPINI_KAP variable obtained a significant value of 0.186 . A significant value greater than $0.05(0.186>0.05)$, and a coefficient value of 43.344 showed Ho8 received and HA8 declined. These results indicate that Audit quality does not moderate the influence of audit opinions.

\section{CONCLUSIONS}

The company's size has no effect on Audit Delay, while profitability of Leverage and the Audit opinion has a significant effect on Audit Delay and Audit quality, moderate the influence of company size and audit Delay, Audit quality moderate the impact of profitability on the Audit Delay. Audit quality moderates the influence of Leverage towards audit Delay. But Audit quality does not moderate the influence of audit opinions.

\section{REFERENCES}

1. Pourali, M. R., Jozi, M., Rostami K. H., Taherpour G. R., dan Niazi, F. (2013). "Investigation of Effective Factors in Audit Delay: Evidence from Tehran Stock Exchange (TSE)". Research Journal of Applied Sciences, Engineering and Technology, 5(2):405-410.

2. Ashton, R., Wilingham, J., \& Elliot, R. (1987). An Empirical Analysis of Audit Delay. Journal of Accounting Research, 25(2), 275-292.

3. Khalatbari, A., Ramezanpour, I., \& Haghdoost, J. (2013). Studying the relationship of earnings quality and Audit delay in accepted companies in Tehran Securities. International Research Journal of Applied and Basic Sciences, 6(5), 549-555.

4. Nurahmayani, I. A., Purnamasari, P., \& Oktaroza, M. L. (2018). Pengaruh Penerapan IFRS, Jenis Industri dan Probabilitas Kebangkrutan terhadap Audit Delay (Pada Perusahaan LQ 45 yang Terdaftar di Bursa Efek Indonesia Periode 20132015). Accruals (Accounting Research Journal of Sutaatmadja), 2(1), 68-81.

5. Lianto, N., \& Kusuma, B. H. (2010). Faktor-faktor yang berpengaruh terhadap audit report lag. Jurnal bisnis dan akuntansi, 12(2), 98-107.

6. Angruningrum, S., \& Wirakusuma, M. G. (2013). Pengaruh profitabilitas, leverage, kompleksitas operasi, reputasi KAP dan komite audit pada audit delay. E-Jurnal Akuntansi Universitas Udayana, 5(2), 251-270.

7. Ayemere, I. L., \& Elijah, A. (2015). Corporate attributes and audit delay in emerging markets: empirical evidence from Nigeria. International Journal of Business and Social Research, 5(3), 110.

8. Carslaw, C. A., \& Kaplan, S. E. (1991). An examination of audit delay: Further evidence from New Zealand. Accounting and business research, 22(85), 21-32.

9. Wulandari, N. P. W., \& Utama, I. M. K. (2016). Reputasi Kantor Akuntan Publik Sebagai Pemoderasi Pengaruh Profitabilitas dan Solvabilitas pada Audit Delay. E-Jurnal Akuntansi Universitas Udayana ISSN, 2302-8556.

10. Puspitasari., S. (2014). Pengaruh Karakteristik Perusahaan Terhadap Lamanya Waktu Penyelesaian Audit (Audit Delay) Pada Perusahaan Manufaktur yang Terdaftar di Bursa Efek Indonesia. Jurnal Akuntansi dan Auditing, Volume 9 Nomor 1. Universitas STIKUBANK. Semarang.

11. Nirmalasari. (2018). Pengaruh Profitabilitas, Leverage, Ukuran Perusahaan Dan Audit Complexity Terhadap Ketepatan Waktu Audit Pada Perusahaan Manufaktur Yang Terdaftar Di Bei Periode 2013 - 2015. Jurnal Kajian Ekonomi dan Kebijakan Publik, 3(2).

12. Hersugondo, S. E., MM, H., Cahyani Nuswandari, S. E., \& Andi Kartika, S. E. (2013). Prediksi probabilitas audit delay dan faktor determinannya. Penelitian Dosen. 
13. Apriliane, Malinda, D. (2015). Analisis FaktorFaktor Yang Mempengaruhi Audit Delay (Studi Empiris Pada Perusahaan Pertambangan Yang Terdaftar Di Bursa Efek Indonesia Tahun 2008 2013). Skripsi. Fakultas Ekonomi Universitas Negeri Yogyakarta.

14. Dewi, A. S. M., Wirajaya, Ary. (2013). Pengaruh Struktur Modal, Profitabilitas, dan Ukuran Perusahaan pada Nilai Perusahaan. E-Jurnal Akuntansi Universitas Udayana, Vol. 4, No.2.

15. Lestari, N. L. K. A. S., \& Latrini, M. Y. (2018). Pengaruh Fee Audit, Ukuran Perusahaan Klien, Ukuran KAP, dan Opini Auditor pada Audit Delay. E-Jurnal Akuntansi Universitas Udayana, 24(1), 422-450.

16. Haryani, J., \& Wiratmaja, I. D. N. (2014). Pengaruh ukuran perusahaan, komite audit, penerapan international financial reporting standards dan kepemilikan publik pada audit delay. E-Jurnal Akuntansi Universitas Udayana, 6(1), 63-78.

17. Hidayat, V. S. (2017). Pengaruh Profitabilitas, Solvabilitas, dan Aktivitas Persediaan terhadap Audit Delay pada Perusahaan Retail yang terdaftar di Bursa Efek Indonesia Periode 2014-2015. Jurnal Akuntansi, 9(2).

18. Fitriana, D., Andini, R., \& Oemar, A. (2016). Pengaruh likuiditas, solvabilitas, profitabilitas, aktivitas dan kebijakan dividen terhadap return saham perusahaan pertambangan yang terdaftar pada BEI periode 2007-2013. Journal of Accounting, 2(2).

19. Nurhayati, M. (2013). Profitability, Liquidity, and Company Size Influence On Dividend Policy and Corporate Value of Non Service Sector. Journal of Finance and Business, 5(2), 145-153.

20. Yuliastuty, R., Situanti, A., \& Situanti, R. (2018). The effect of audit tenure and firm size on financial reporting delays.

21. Wirakusuma, M. G. (2004). Faktor-Faktor yang Mempengaruhi Rentang Waktu Penyajian Laporan Keuangan ke Publik (Studi Empiris Mengenai Keberadaan Divisi Internal Audit pada PerusahaanPerusahaan yang Terdaftar di Bursa Efek Jakarta. Simposium Nasional Akuntansi VII, 12021222.

22. Andi, K. (2009). Faktor-Faktor Yang Mempengaruhi Audit Delay di Indonesia (Studi Empiris Pada Perusahaan-Perusahaa LQ 45 Yang Terdaftar di Bursa Efek Jakarta). Jurnal Bisnis dan Ekonomi (JBE), Fakultas Ekonomi Universitas Stikubank Semarang.

23. Suharli, M., \& Oktorina, M. (2005). Memprediksi tingkat pengembalian investasi pada equity securities melalui rasio profitabilitas, likuiditas, dan hutang pada perusahaan publik di Jakarta. Kumpulan Makalah Simposium Nasional Akuntansi, 8, 288-295. 